\title{
The United Nations and Business: Towards New Modes of Global Governance?
}

\author{
Carlos Fortin and Richard Jolly
}

\begin{abstract}
In the last decade and a half there have been sustained efforts on the part of the United Nations to bring the business sector into formal arrangements for dialogue and cooperation and to codify United Nations policies vis-a-vis business in order to give the relationship a more structured footing. This article reviews some of the most prominent of those efforts. In particular, it evaluates the available evidence about the extent to which they are achieving the aim of mobilising the skills and resources of private business for the furtherance of the goals of the United Nations; and about some of the main concerns raised by the $\mathrm{UN}$-business interface, including the possible instrumentalisation of the relationship to gain public legitimacy or as a vehicle for business to influence United Nations policies and actions. It concludes that further research is needed to address these questions in a systematic manner.
\end{abstract}

\section{Introduction}

The place of business in the United Nations has always been somewhat ambiguous. To be sure, the United Nations is an organisation of governments, where in principle private entities have no standing; the only exception is the International Labour Organization (ILO), whose formal governance structure includes governments, trade unions and employer organisations.

From the start, however, the United Nations sought to engage non-state actors in its work. Non-governmental organisations (NGOs) had taken up consultative status at the Economic and Social Council (ECOSOC) as early as 1946, and currently there are some 3,900 entities in that category, which extends to all subsidiary bodies of ECOSOC. Organisations with consultative status include international, regional and national NGOs, and non-profit public and voluntary organisations; the status entitles them to attend UN meetings and conferences, propose agenda items, circulate written statements and make oral statements if specifically authorised to do so. ${ }^{2}$

None of this, however, applies to business enterprises. While employer organisations are eligible for consultative status, individual companies are not. And yet, it is evident that business can play a major role in the pursuance - or the defeat - of international goals that are a central part of the United Nations mandate; some that immediately spring to mind are the protection of human rights and the environment, the fight against poverty and against corruption, and the achievement of economic and social development. These roles of business have been of growing importance in the last two decades, both because UN goals have achieved a widespread consensus among governments and because business and multinational corporations have themselves grown in influence and impact in more and more countries of the world.

By the same token, many United Nations initiatives and actions are of interest to the private business sector, inasmuch as they may affect their mode of operation and in the end their profitability. Executives of private firms are routinely included in national delegations to negotiating fora, particularly by developed countries; companies sometimes lobby meetings and delegations, as well as Secretariats, in some instances with great impact. ${ }^{3}$ 
Moreover, the operational and funding agencies of the United Nations have long been purchasers and partners with individual firms and as such they have a capacity to exert influence on the behaviour of a number of businesses and corporations; this is especially so in the areas of health and pharmaceutical production and marketing.

It is therefore not surprising that in the last decade and a half there have been sustained efforts on the part of the United Nations to bring the business sector, and specifically individual companies, into more formal arrangements for discussion and cooperation; and to codify the policies of the United Nations vis-à-vis business to give the relationship a more structured footing.

This article will review some of the most prominent of those efforts, to assess their degree of success and explore the issues they raise in connection with both the achievement of United Nations goals and with the manner in which United Nations governance is evolving.

In particular, it will evaluate the available evidence about the extent to which they are achieving the aim of mobilising the skills and resources of private business for the furtherance of the goals of the United Nations. It will further address some of the main concerns raised by the $\mathrm{UN}$-business interface, namely, is the relationship with the United Nations essentially a means for business to gain public legitimacy? Can it become a vehicle for business to influence United Nations policies and actions? How effective is self-regulation as an approach to the governance of the relationship?

\section{The new modes of engagement and the issues}

UN-business relationships have developed into a wide array of different types. Within them five basic modes of engagement can be distinguished:

1 Enlisting the cooperation of business in achieving fundamental international goals;

2 Developing value-oriented norms and standards applicable to both governments and business with a view to preventing violations of the fundamental goals;

3 Developing technical standards in international production and trade;

4 Providing venues for dialogue and the exchange of information and views among governments, private business companies and civil society; and
5 Where applicable, exercising market power to influence the prices and availability of goods and services so as to maximise their development impact.

All of them - in different ways and to different degrees - raise some common issues. ${ }^{4} \mathrm{~A}$ first issue has to do with measuring the impact of the engagements. Here the familiar nomenclature of the results-based management framework is helpful (see UNDP 2002). It distinguishes activities, outputs (completed activities), outcomes (intermediate effects) and impact (longer run effects); the categories are not rigidly delimited, and there are overlaps. As will be seen below, the assessment of impact varies as among the above four meanings and among the five modes of engagement described.

A second issue has to do with the voluntary character of the engagements and the consequent absence of mechanisms for enforcing and, in some cases, even monitoring compliance. There is a criticism that this substantially diminishes the possibility of the schemes having real impact and indeed opens up the possibility of the existence of voluntary schemes being used by business as an argument to prevent or at least delay the introduction of binding arrangements (the 'self-regulation' issue).

A third issue stems also from the voluntary character of the engagements, and is a question of the extent to which companies could in effect use their association with the UN to enhance their reputation without changing their corporate behaviour (the 'bluewash' issue).

Finally, there is the question as to whether participation in the various schemes provides business with the opportunity to influence UN policy thinking on corporate social responsibility (CSR), international trade and foreign direct investment in ways consistent with business interests (the 'capture' issue).

In the next section we provide a brief description of a selected number of initiatives chosen in terms of their potential impact on the goals of the UN and on its governance arrangements. The subsequent section will explore the issues raised as they apply to the different kinds of UN-business engagements. 


\section{The main initiatives}

\subsection{Engaging the cooperation of business}

The United Nations Global Compact. The

flagship initiative under this heading is the United Nations Global Compact promoted by the Secretary General, Kofi Annan, and launched in July 2000. While primarily addressed to business, it also includes governments, labour and civil society organisations, with the UN as convenor and facilitator. The Compact involves a commitment from business to align operations and strategies with ten principles in the areas of human rights, labour, environment and anticorruption. ${ }^{5}$ It also involves a commitment to engage in a structured dialogue with all other stakeholders about what is deemed to constitute good practice, the 'learning network' element (Ruggie 2001; Knight 2002; see also Rasche and Kell 2010; Fritsch 2008; Whitehouse 2003); and a willingness to join the UN in partnership projects to benefit developing countries. Currently there are some 12,000 participants, of which 8,000 are companies, in 145 countries (United Nations Global Compact 2014; Rasche, Waddock and McIntosh 2013 includes a comprehensive bibliography on the Compact).

A central feature of the Global Compact is that it does not entail legally binding commitments. The Compact's web page emphasises that 'it is not a regulatory instrument but rather a voluntary initiative that relies on public accountability, transparency and disclosure to complement regulation and to provide a space for innovation and collective action' (United Nations Global Compact 2014).

\section{The United Nations Development Programme (UNDP) Business Call to Action. This was} launched in 2008. It is described as 'a global initiative that seeks to harness the power of business investments to reduce extreme poverty and improve the lives of millions... by challenging companies to develop inclusive business models that offer the potential for both commercial success and development impact' (UNDP n.d.).

As of 2014 the initiative comprised 89 companies from Sweden, the UK, the Netherlands, the US, Brazil, India, the Philippines and Turkey.

Company commitments span the areas of green technology, agriculture, financial services, health and sanitation and include providing 1.8 million jobs, vocational training for 3 million people, and improving nutrition for 1.2 million people (Business Call to Action n.d.). ${ }^{6,7}$

\subsection{Developing value-oriented norms and standards The UN Guiding Principles on Business and Human Rights. Endorsed by the UN Human} Rights Council in June 2011, these are described in the Interpretive Guide issued by the UN High Commissioner for Human Rights as 'the global standard of practice that is now expected of all States and businesses with regard to business and human rights' (OHCHR 2012: 1).

The Principles are based on a framework proposed by Special Representative of the UN Secretary General Professor John Ruggie which identifies three pillars for state and business duties in connection with human rights: Protect, Respect, Remedy. The Principles, 31 in all, are divided between those addressed to states and those addressed to business.

The Guiding Principles are, again, not legally binding in themselves, but 'elaborate on the implications of existing standards and practices for States and businesses, and include points covered variously in international and domestic law' (OHCHR 2012: 1).

There is clearly a certain degree of overlap between the Guiding Principles and the Global Compact, and this has been clarified by a joint statement (United Nations Global Compact and OHCHR 2011).

Other efforts of this sort include the ILO Tripartite Declaration of Principles Concerning Multinational Enterprises and Social Policy adopted by the Governing Body of the ILO in November 1977 and the United Nations Children's Fund (UNICEF) Children's Rights and Business Principles developed by UNICEF, the UN Global Compact and Save the Children (UNICEF n.d.a).

\section{The World Health Organization (WHO)/UNICEF International Code of Marketing of Breast-milk} Substitutes. This was adopted in 1981 by the World Health Assembly. Its purpose is to protect breastfeeding against unethical marketing practices of the breast milk substitute industry.

The Code contains, among others, prohibitions to advertise breast milk substitutes, to give free 


\section{Box 1 The UN using its own market power}

The UN Funds and Specialized Agencies spend several billions of dollars each year in support of health, education, water and sanitation services and investments, often directed to children and vulnerable groups living in rural or peri-urban areas. Although the sums involved are considerably less than those expended by the World Bank and the Regional Development Banks and by aid donors in direct support of governments, the leverage of UN expenditure has often been used to promote low-cost, people-focused approaches with pioneering effects in terms of new technologies, prices and market operations.

One clear example was in the early 1970s, when UNICEF was widely engaged in drilling tube wells in India and installing a variety of hand pumps, many of inadequate cast-iron design. After evidence showed a very high rate of breakdown, UNICEF worked with Indian engineers and manufacturers to develop what became the Indian Mark II hand pump, which was low cost, sturdy and reliable but easily repairable, suitable for installing in villages with deep tube wells. It was initially designed so that a local village mechanic could easily make the repair, with later modifications consciously designed so that village women, the main users, could manage the maintenance and repair themselves. Initially, UNICEF itself directly supported manufacture, but by 1984 hand pump production had become an established industry, with over 60 local manufacturers producing 300,000 hand pumps a year, many for export; UNICEF then moved to standardisation, quality control and purchase. To date, over four million Indian Mark II hand pumps have been manufactured and installed, widely in Asia and Africa.

For its immunisation campaigns, UNICEF with WHO also encouraged the development of equipment and supplies suitable for use in the rural areas of poorer countries, for instance non-reusable syringes, vaccines more tolerant to tropical temperatures or not requiring the use of a cold chain for delivery. In recent years, these activities have also found support from Gavi and the Gates Foundation.

An impressive example of using market power with widespread effects was the Danishsupported programme for supplying essential drugs to rural health clinics in Tanzania. An open system of competitive bidding for the supply of a core list of 32 basic medicines was used. This resulted in a substantial reduction of costs, some 40 per cent below what was anticipated. UNICEF and WHO began to issue quarterly price lists based on these prices, recommending governments elsewhere to use them as guidelines for their own supplies and, if not available, they could obtain supplies at these prices direct from UNICEF.

Although, again, the sums involved in these purchases may be small compared to the global market of pharmaceutical products, the focused purchases by the UN of products for use in poorer countries has often encouraged the companies to develop low-cost supplies (and low-cost solutions) better adapted to the conditions in poorer countries. The level of mass purchase is usually beyond the reach of individual small and poorer countries acting alone. This was true in the early days of HIV/AIDS when UNICEF and WHO, with the support of many NGOs, pressured companies to lower prices of anti-retroviral drugs many times below those they were charging in developed countries. 
samples of breast milk substitutes to mothers and to promote breast milk substitutes in healthcare facilities.

The Code itself was adopted as a

Recommendation and therefore is not legally binding by itself. However, Art. 24 of the Convention on the Rights of the Child has been interpreted by the Committee on the Rights of the Child as requiring governments to take steps to implement it through national legislation.

The most recent report on the status of implementation of the Code (UNICEF 2011) shows that 81 countries had enacted legislation or other legal measures encompassing all or many provisions, while 30 others had adopted a few provisions or most of them on a voluntary basis. Countries are often under considerable pressure from companies which manufacture breast milk substitutes not to adopt the Code or to make exceptions to some of its provisions, a point we come back to below.

\subsection{Developing technical standards}

One activity stands out here: Codex

Alimentarius. The Codex Alimentarius Commission, established by the Food and Agriculture Organization (FAO) and WHO in 1963, develops harmonised international food standards, guidelines and codes of practice.

According to its Statute its purpose is 'protecting the health of the consumers and ensuring fair practices in the food trade' (Art. 1(a)). As of 2014 it comprises 186 Codex Members - 185 Member Countries and one Member Organisation (EU) and 224 Codex Observers, of which 52 are intergovernmental organisations, 157 are NGOs and 15 are $\mathrm{UN}$ organisations (WHO/FAO n.d.).

The Codex standards are not binding but rather recommendations to the members for voluntary application. In effect, however, they are very widely applied, and in many cases have served as a basis for national legislation and regulation. Furthermore, the Agreement on the Application of Sanitary and Phytosanitary Measures of the World Trade Organization has given the Codex a measure of legal status in its dispute settlement process (WTO 1994).

This has led to the private business sector becoming very interested in taking part in the work of the Commission and particularly of its technical subsidiary bodies. While individual companies are not eligible for observer status, they are often included in national delegations; furthermore, business associations can be observers, and they have a strong presence in meetings and activities generally.

\subsection{Providing venues for dialogue}

The United Nations Conference on Trade Development (UNCTAD) World Investment

Forum is a biennial event designed to facilitate dialogue, and eventually action, among the main actors in the world's investment economy (UNCTAD 2014).

In the 2014 Forum, speakers included 43 representatives of governments, 58 high executives of international business companies, including 29 CEOs, and representatives of 19 stock exchanges. Discussions covered a wide range of topics, including: Investing in Sustainable and Universal Access to Medicines: Local Production in Developing Countries; Women's Empowerment and Gender Equality the Role of Transnational Corporations (TNGs); Human Rights and Investment Policy Making: Relevance and Integration; Making Value Chains Work for the Poor; Reforming the International Investment Agreements Regime.

\subsection{Exercising market power} UNICEF/WHO and the pricing of pharmaceuticals. As major purchasers of essential drugs and other products in sizable quantities, UNICEF and WHO have used their market power to reduce substantially the prices of pharmaceutical products, for instance essential supplies for clinics and anti-retroviral drugs. Such actions have achieved extended impact by publishing and disseminating the lower prices achieved and encouraging developing countries to use them for their own purchases (see Box 1).

\section{Back to the issues}

\subsection{Measuring impact}

How do the selected initiatives perform in the light of the issues identified in Section 2 above?

On the issue of impact, a common feature is the indeterminacy as far as the ultimate effects are concerned. As has been suggested in an evaluation of the Global Compact - but applicable to the other efforts - the ultimate goal is 'promoting inclusive globalisation' (McKinsey \& Company 
2004: 1). The evaluation goes on to state that 'an attempt to assess the Compact's impact on the ultimate goal of promoting inclusive globalisation would have been spurious, given the many variables that affect it' (McKinsey \& Company 2004: 1-2). ${ }^{9}$ In the very nature of this broad goal it is simply not possible to assess the success or otherwise of the endeavours.

By contrast, when it comes to activities and outputs, some assessment is possible, and it is, on the whole, a favourable one. Figures have been quoted above of the number of companies responding to the various demarches for engagement, and they are by and large impressive. So are activities and outputs in pursuance of the programmes, whether they are network meetings, workshops, webinars and newsletters in the case of the Global Compact (see as an example, Global Compact Network United Kingdom 2014); the launching of projects under the UNDP Business Call to Action (Business Call to Action 2013, n.d.); the work on implementation of the Guiding Principles by the Working Group on Business and Human Rights (Business and Human Rights Resource Centre n.d.) and by a number of governments, intergovernmental organisations and international NGOs (Ruggie 2014); the number of standards produced by the Codex Alimentarius (339; see WHO/FAO 2014) and by the Economic Commission for Europe (UNEGE) (118; see UNECE n.d.b); the Interagency Roundtables on Corporate Social Responsibility (CSR) and the Global CSR Retreats organised by UNCTAD.

The jury, however, is still out on whether the main outcome sought - influencing the actual behaviour of business in strategic and fundamental areas such as furthering human rights, the protection of the environment and development - is being achieved.

The issue is particularly relevant for the Global Compact. An early - but still the only systematic effort at evaluating its outcomes (McKinsey \& Company 2004) concluded that, on balance, there was a positive effect. The study finds that the Global Compact has had noticeable, incremental impact on companies, the UN, governments and other civil society actors and has built a strong base for future results. The Compact has primarily accelerated policy change in companies, while catalysing a proliferation of 'partnership projects', development-oriented activities that companies undertake with UN agencies and other partners (McKinsey \& Company 2004: 2).

This positive conclusion, however, is tempered by the recognition that 'inconsistent participation and divergent and unmet expectations limit the impact on companies and continue to threaten the Compact's long-term credibility with participants' (McKinsey \& Company 2004: 2).

The point has been subsequently confirmed by an exercise carried out since 2007 by the Compact itself, the Global Compact Annual Implementation Survey. ${ }^{10}$ The Survey probes essentially into activities and outputs rather than outcomes or impact. Even at this level, however, it acknowledges problems. On the basis of the 2012 Survey, the Compact's 2013 Global Corporate Sustainability Report states that:

Survey findings point to a clear gap between the 'say' and 'do' steps of the Global Compact Management Model. Companies are making commitments, defining goals and setting policies at high rates, but still have much work to do to [sic] on the action steps: implement, measure and communicate. For example, while 65 per cent of signatories are committing to sustainability at the CEO level, only 35 per cent are training managers to integrate sustainability into strategy and operations (United Nations Global Compact 2013: 7).

Compact officials and sympathetic commentators have emphasised that any effort at evaluating the impact of the initiative should take into account the learning function of the Compact. Some analysts have gone as far as to suggest that the main contribution of the Compact lies in exemplifying a new form of governance, 'a new set of international practices that has been referred to as "complex multilateralism... the Compact is a striking manifestation of this evolution toward a bottom-up, nonhierarchical model of multilateral cooperation"' (Thérien and Pouliot 2006: 57; see also Fritsch 2008). We shall come back to this assessment below in connection with the 'capture' issue; it has been argued that the learning network approach compounds it inasmuch as the weight of business in the networks could be disproportionate to that of NGOs and other participants. 


\subsection{Self-regulation}

The question of impact is closely related to the debate about self-regulation as a mode of governance of the relationship between the UN and business. Reference has already been made to the view that this is essentially an ineffectual mechanism, and one that might in fact be counterproductive inasmuch as it might provide arguments against the adoption of binding, monitorable and enforceable international commitments. ${ }^{11}$ The opposing view is that contemporary civil regulation is fundamentally different from traditional industry selfregulation: while the latter is typically exclusively governed and controlled by firms, the governance of civil regulations is more likely to be transparent, contested, and to either formally or informally involve stakeholders outside the firm (Vogel 2010: 70). It has been further argued that any realistic assessment of civil regulation should compare it not to an ideal world of effective global economic governance but to actual policy alternatives.

When compared to most government regulations in developed countries, civil regulation is clearly less effective... But the effectiveness of civil regulations is roughly comparable to that of many intergovernmental treaties and agreements, whose effectiveness in addressing environmental protection, labour practices, and human rights is also mixed and uneven (Vogel 2010: 80).

The issue of self-regulation has been hotly debated in connection with the Guiding Principles on Business and Human Rights. It will be recalled that in 2003 a Sub-Commission of the UN Commission on Human Rights had adopted a set of norms on the responsibilities of TNGs and other business enterprises with regard to human rights. The norms constituted a 'nonvoluntary', comprehensive framework, creating direct obligations for TNGs and supplemented by a rigid enforcement mechanism including the monitoring by non-state actors (NGOs and TNGs themselves).

The norms were approved by the SubCommission despite strong opposition from business and from many governments, including of developing countries. The Commission itself did not adopt them and instead asked the UN
Secretary General to appoint a Special

Representative to review the whole matter of corporations and human rights. In July 2005, Professor John Ruggie was appointed as the Special Representative and went on to propose the Guiding Principles three years later. ${ }^{12}$

A main argument of governments against the norms was that they departed from the existing frameworks of international law by attempting to impose duties and obligations on non-state actors, while these were applicable solely to states (Miretski and Bachmann 2012: 33). Professor Ruggie did not take the view that companies cannot be bearers of duties under international law, but felt they cannot have the same range of duties as states. He further felt that the conditions were not ripe for a binding international instrument.

As a result, and as already indicated, the Guiding Principles are not - and are not intended to be - legally binding in themselves. Although some are addressed directly at business, they are not justiciable as far as business is concerned. This did not satisfy NGOs and activists who insisted on having a legally binding instrument that would establish specific obligations for companies. ${ }^{13}$

The issue was taken up by a group of countries (Bolivia, Cuba, Ecuador, South Africa and Venezuela) which proposed a resolution to the UN Human Rights Council which establishes an open-ended intergovernmental working group with the mandate to elaborate an international legally binding instrument on TNGs and other business enterprises with respect to human rights (UN Human Rights Council 2014). It was adopted by a vote of 20 in favour, 14 against and 13 abstentions; all OECD countries voted against and all Latin American countries, except for Cuba and Venezuela, abstained. ${ }^{14}$ Countries voting against argued that the proposed intergovernmental group would create a competing initiative that would undermine efforts to implement the Guiding Principles, which should remain the main focus of international action in this field.

The decision of the Council prompted an extended comment by Professor Ruggie in which he reiterates his misgivings about a binding instrument at this stage (Ruggie 2014). He 
points to the weak political mandate, passed not with a majority but a plurality of votes in the Council (China, in effect, while voting in favour, entered a number of reservations); and the excessively broad scale of the proposed Code: '.... it encompasses too many complex areas of national and international law for a single treaty instrument to resolve across the full range of internationally recognized human rights'. In Professor Ruggie's view, the way forward involves the intergovernmental working group to bring into its discussions civil society and business, including individual firms from all regions; carrying out basic research into relevant precedents/models, needs and scope as a prerequisite of textual negotiations; and linking this initiative to the Guiding Principles, with a strong commitment to their implementation.

Professor Ruggie's proposals reflect his overall approach to these issues, which he has termed 'principled pragmatism' and defined as:

an unflinching commitment to the principle of strengthening the promotion and protection of human rights as it relates to business, coupled with a pragmatic attachment to what works best in creating change where it matters most - in the daily lives of people (Ruggie 2013: xlii-xliii).

We shall return to this notion in the next section.

\section{3 'Bluewash'}

The 'bluewash' issue has been discussed particularly in connection with the Global Compact (Bruno 2002). Critics of the initiative have pointed to the potential danger of companies joining the Compact solely for purposes of acquiring public legitimacy, without serious intention to implement the principles. The first Global Compact Annual Implementation Survey produced in 2007 seemed to lend some credibility to the fears. In response to the question, 'What are the reasons for your organization's participation in the Global Compact?', 63 per cent of the companies mentioned 'increase trust in company' and 43 per cent indicated 'improve public relations'.

The Compact has taken steps to address the problem by introducing changes in the monitoring requirements as well as a instituting a set of Integrity Measures. On monitoring it established a requirement that participating companies issue an annual Communication on Progress (COP), a public disclosure on progress made in implementing the ten principles and in supporting broader UN development goals. The Integrity Measures, in turn, included:

\section{- Limitations on the use of the Global} Compact's name and logos to certain authorised users and instances only;

- Sanctioning the failure to issue a COP with changing a participant's status to noncommunicating and eventually the expulsion of the participant; and

- A procedure to deal with allegations of systematic or egregious abuse of the Global Compact's overall aims and principles, leading if necessary to the designation of the company as non-communicating and to expulsion.

By the end of 2012, the Compact had delisted nearly 4,000 companies but, in the words of its Executive Director, there was still a long way to go dealing with 'free riders who joined but had no intention to stay engaged' (Confino 2012; see also Knudsen 2011).

A particularly contentious issue arises in connection with the compliance by Global Compact participant companies with the WHO/UNICEF International Code of Marketing of Breast-milk Substitutes. The International Baby Food Action Network (IBFAN) published in 2014 a report documenting 813 violations of the Code by 27 companies in 81 countries between January 2011 and December 2013 (IBFAN 2014). Such violations have continued for many years and, though challenged, have been upheld when investigated by independent bodies. Six of the companies named are either members of the Compact, or owned by member companies, or have subsidiaries which are members. They include the two global leaders in the baby food market, Nestlé and Danone.

There are also documented cases of pressures from member companies, directly or through their own governments, on countries not to adopt the Code or to relax its application. A highly publicised instance was the intervention of the United States government vis-à-vis the government of Vietnam in June 2012 urging the rejection of a proposal to extend a ban on 
advertising formula milk products for babies younger than 12 months to cover babies younger than 24 months. The proposal was to be voted by the Vietnamese National Assembly. IBFAN managed to obtain, and published, a letter from the US Embassy in Hanoi addressed to the Chairman of the Assembly and to three ministers, which read: 'Several US companies have contacted the US Embassy regarding their serious concerns about this proposed prohibition on advertising of formula milk products, which could have a significant negative impact on their business in Vietnam. We share their concerns. ${ }^{15}$ According to IBFAN, one of the companies involved in the lobbying was a member of the Compact. To its credit, the Vietnamese National Assembly nevertheless adopted the proposal (Infact Canada 2012).

Particularly criticised have been the efforts by Nestlé to argue that some of its products do not fall within the scope of the Code as they are not substitutes for, but supplements to, breastfeeding. ${ }^{16}$ Such arguments have been carefully considered and rejected by WHO and UNICEF, who have stated and restated that exclusive breastfeeding for the first six months is best for all children - and sufficient in all but exceptional cases. After six months, supplementary feeding is needed, but this can be in the form of solid foods with breastfeeding continued, where possible well into the second year. The life-saving importance of these recommendations is that most poor families in developing countries do not have the safe water and other facilities needed for using breast milk substitutes properly. Another big factor is the immunological benefits which are passed from mother to child through milk. In 2014, UNICEF estimated that a breastfed child has six times more chance of surviving to five years than a bottle-fed child and The Lancet journal estimated in 2013 that the deaths of 800,000 young children could be prevented if optimal breastfeeding was adopted (UNICEF n.d.b).

Accusations of 'bluewashing' have also been made against UNDP's Business Call to Action among others by the respected development NGO War on Want for including 'corporations that have been widely attacked for deepening poverty and undermining human rights' (War on Want n.d.).

\section{4 'Capture'}

'Capture' refers to the fact that:

partnership with the UN not only provides opportunities for business to pursue more directly its own policy interests within the UN, but the public purpose of the UN becomes subverted if it begins to promote the policy goals preferred by business when these are far from universally approved (Zammit 2003: xxi).

The problem might in fact extend to the relationship with NGOs and other organisations in the light of the emphasis on 'learning networks' referred to above. To quote Zammit again:

Initiatives to encourage companies to improve CSR include a range of actions... encourage dialogue and 'social learning' among the participants... For many of the protagonists, these arrangements are considered the optimal rather than second-best policy solution as they embody the newly fashionable notions of dialogue, responsibility, voluntary interaction, and co-operation between community and corporate interests... However, these close relations between civil society groups and the more powerful government institutions and businesses carry with them the risk of 'capture', that is, the distortion of the priorities and practices of NGOs and similar groups (Zammit 2003: 40).

The issue of 'capture' has been particularly prominent in connection with work on technical standards. Specifically, the Codex Alimentarius has been accused of being unduly influenced by corporate interests represented by trade organisations which have observer status at the Commission and its Committees (Verkerk n.d.). By contrast, programmes that provide venues for discussion and dialogue have, on the whole, escaped this criticism. Specifically, UNCTAD's World Investment Forum has been generally regarded as a serious effort to examine issues concerning foreign direct investment and the balance between the protection of foreign investors and the right of governments to regulate in the national interest.

\section{Summing up and conclusions: Bringing business in, the way forward}

The preceding review of developments and issues in UN efforts to engage the business sector in 
the achievement of its basic goals should have alerted us to the complexities of the venture and its many possible pitfalls. And yet the genie is out of the bottle and the question is, what is the way forward?

The analysis above identified various forms by which the UN has sought business engagement. While conceding that an evaluation of the achievement of the ultimate goal of an inclusive globalisation is highly problematic, given the complex constellation of variables involved, the discussion suggested that an evaluation of activities and outputs was possible and that, where it has been carried out, it has shown a degree of progress. The question remains, however, whether the activities and specific outcomes are of the sort that, in the words of the McKinsey report, support 'the necessary and sufficient conditions for making progress toward the ultimate goal' (McKinsey \& Company 2004: 2).

The analysis also strongly suggested that claims that bringing business into UN processes amounts to a fundamental change in the mode of governance of the organisation are exaggerated. The UN remains an intergovernmental organisation and governments - both from developed and developing countries - are the first custodians of that principle, as shown by the brief account above of the process leading up to the adoption of the Guiding Principles on Business and Human Rights.

Opening up the workings of the UN to non-state actors, however, is a trend of the times, and will continue. The presence of business in UN processes, both as partner and as bearer of duties and obligations, is very likely to increase. This raises the vexed question of whether the UN should issue legally binding injunctions or trust business to self-regulate and comply voluntarily. Quite apart from consideration of effectiveness, it would seem that the political economy arguments advanced by Professor Ruggie should carry the day. The chances of an international convention establishing binding obligations for business are simply, at least in the short to medium term, not high. In the circumstances, Professor Ruggie's approach, 'principled pragmatism', recommends itself: go as far as possible in the direction of legal obligation but without forcing the pace unduly. Specifically, an area which appears promising in this regard is that of remedies available to individuals for violations of human rights committed by business concerns. A resolution mandating a consultative exploration of this issue has already been adopted by consensus by the Council on Human Rights. ${ }^{17}$

The preceding suggests that the question of noncompliance and the related issue of 'bluewashing' are unlikely to be addressed by means of sanctions. The way forward here is to reinforce monitoring mechanisms and transparency. The introduction of the Communication of Progress and the Integrity Measures in the Global Compact are an important step in this direction and have already produced some visible results in the form of delisting delinquent companies.

The issue of 'capture' is a particularly difficult one. Without necessarily accepting all denunciations, it seems apparent that in some contexts business, especially TNCs, wield disproportionate influence, even more when their interests are supported by powerful governments. Here there are two important ways forward: one is participation of other non-state actors, including NGOs, various parts of the UN itself, international organisations, academic institutions, labour unions, etc. They can perform a useful function as watchdogs as well as provide alternative voices. A second is building closer links with regional and sub-regional organisations which have in some cases adopted regulations of TNGs and other business operations in areas where the UN itself has been unable to act. A case in point is the OECD Guidelines for Multinational Enterprises (OECD 2011).

Finally, the concept of the Global Compact as an instance of network learning is promising as long as it is kept in mind that what is at stake here is not only a technical, problem-solving, process, but that there are potential conflicts of interest between government and business which will call for political debate and decision in the appropriate intergovernmental UN bodies.

All these suggestions, however, are based on preliminary assessments made on the strength of the incomplete and mostly anecdotal evidence available. We still do not have systematic and comprehensive empirical analyses on the profiles of the 'business' engaged with the UN, or on the way in which their role in global governance and their incentives have changed as a result of UN 
engagement. More specifically, what have been the effects of the various programmes in terms of intermediate outcomes in the direction of the ultimate goals? Can we identify the conditions under which they are successful, and how do they differ for different types of businesses? Has selfregulation been effective in helping steer the behaviour of business in the desired directions? Has 'bluewashing' been a serious problem? To what extent has business attempted to influence UN policies and actions to further its own

\section{Notes}

1 A point documented in detail in Tesner (2000).

2 NGO observers on similar bases are also allowed by other UN bodies which are not ECOSOG subsidiaries, such as the United Nations Conference on Trade and Development (UNCTAD), specialised agencies and treaty bodies.

3 A textbook example is the negotiation of the Agreement on Trade-Related Aspects of Intellectual Property Rights (TRIPS) in the World Trade Organization (WTO), where the presence of pharmaceutical multinational companies was very much in evidence throughout the process (see Sell 2003). The WTO is not a specialised agency of the UN but as a member of the UN System Chief Executives Board for Coordination (CEB) is part of the broad UN system of institutions.

4 For a good discussion of many of the points raised by this conceptualisation see Zammit (2003). See also Utting (2000 and 2003).

5 They are: support and respect the protection of internationally proclaimed human rights; avoid complicity in human rights abuses; uphold the freedom of association and the right to collective bargaining; elimination of compulsory labour; abolition of child labour; elimination of discrimination in respect of employment and occupation; a precautionary approach to environmental challenges; promote greater environmental responsibility; encourage the development and diffusion of environmentally friendly technologies; work against corruption, including extortion and bribery (United Nations Global Compact 2014).

6 The UNDP also enters into partnership with private companies in the course of its regular technical cooperation activities.

7 Mention should be made here of the Partnerships for Sustainable Development, an initiative launched at the Johannesburg World interests? How has the presence of business impacted on the governance mechanisms of the UN and the shaping of UN processes?

The state of knowledge about the UN-business relationship suggests, therefore, a rich and complex research agenda. To tackle it is no doubt a pre-requisite for further serious progress in the effort to engage the business sector in the pursuance of the goals of the UN.

Summit on Sustainable Development in 2002, defined as 'multi-stakeholder initiatives voluntarily undertaken by Governments, intergovernmental organizations, major groups and others stakeholders to contribute to the Implementation of inter-governmentally agreed development goals and commitments, as included in Agenda 21, the Johannesburg Plan of Implementation, the Millennium Declaration, the outcome document of the United Nations Conference on Sustainable Development (Rio+20) entitled "The Future We Want", and the upcoming post-2015 sustainable development agenda' (UN DESA 2014: 2). While these are not strictly UN activities, they are registered with the United Nations Commission on Sustainable Development and in a few cases UN agencies participate.

8 Another example worth mentioning in this category is the United Nations Economic Commission for Europe Agricultural Quality Standards (UNECE n.d.a).

9 The evaluation further defines its more narrow aim as assessing 'the Compact's success in supporting the necessary and sufficient conditions for making progress toward the ultimate goal'.

10 This is an anonymous online survey which all companies participating in the Compact are invited to take. The response in 2012 - the last one available - was 25 per cent. The Survey was administered and analysed by the Wharton School of the University of Pennsylvania.

11 The point is sharply put by James Paul, executive director of the Global Policy Forum commenting on the Global Compact: 'By establishing this blue-chip minimalism, they hope to avoid something that would be a more serious (and effective) means of accountability/ regulation at the global level' (cited in Turner 2004). 
12 For a detailed account see Ruggie (2013).

13 See Weissbrodt (2006); and NGO (2006) where 92 NGOs call on the Special Representative of the Secretary-General (SRSG) 'to take into consideration the growing body of legal jurisprudence and doctrine concerning the direct applicability of international law to private actors' and 'to make recommendations about the means by which appropriate legal standards might be elaborated, adopted and, eventually, implemented'.

14 Bolivia and Ecuador are not members of the Council.

15 Available at www.infactcanada.ca/pdf/ vietnam-us-embassy-letter.pdf (accessed 15 December 2014).

\section{References}

Bruno, K. (2002) Greenwash + 10. The UN's Global Compact, Corporate Accountability and the Johannesburg Earth Summit, San Francisco, California CA: CorpWatch, http://s3.amazonaws.com/corpwatch.org/down loads/gw10.pdf (accessed 15 December 2014)

Business and Human Rights Resource Centre (n.d.) About the Working Group, http://businesshumanrights.org/working-group/about-theworking-group (accessed 15 December 2014)

Business Call to Action (n.d.) Case Studies, www.businesscalltoaction.org/category/media/ case-studies (accessed 15 December 2014)

Business Call to Action (2013) Inclusive Business Gains Momentum, Annual Review 2013, www.businesscalltoaction.org/wp-content/ uploads/2014/09/BCtA_AnnualReview2013 Web.pdf (accessed 15 December 2014)

Confino, J. (2012) 'Cleaning up the Global Compact: Dealing with Corporate Free Riders', The Guardian Professional Network, 26 March, www.theguardian.com/sustainablebusiness/cleaning-up-un-global-compactgreen-wash (accessed 15 December 2014)

Fritsch, S. (2008) 'The UN Global Compact and the Global Governance of Corporate Social Responsibility: Complex Multilateralism for a More Human Globalisation?', Global Society 22.1: $1-26$

Global Compact Network United Kingdom (2014) Past Events Report 2014, www.unglobalcompact.org.uk/events/past-eventsreports-2014 (accessed 15 December 2014)

IBFAN (International Baby Food Action Network) (2014) Breaking the Rules, Stretching the Rules 2014, Penang, Malaysia: IBFAN Sdn
16 For an assessment done by a private consultancy firm that presents in some detail Nestlé's case, see Paceth (n.d.) Nestlé joined the Global Compact in 2001 and is a founding member of the Compact's LEAD initiative, defined as 'a leadership platform comprising a group of "champion" companies that support UNGG participants in their efforts to achieve higher levels of corporate sustainability performance' (Nestlé S.A. 2013: 41).

17 UN Document A/HRC/26/L.1, Rev.1.

Bhd, summary at www.babymilkaction.org/wpcontent/uploads/2014/05/BTR14inbrief.pdf (accessed 5 February 2015)

ILO (International Labour Organization) (n.d.) Tripartite Declaration of Principles Concerning Multinational Enterprises and Social Policy, www.ilo.org/wcmsp5/groups/public/_-ed_emp/ -emp_ent/-multi/documents/publication/ wcms_094386.pdf (accessed 15 December 2014) Infact Cánada (2012) US Pressures Vietnam Against Extending Laws Banning Formula Advertising from 12 Months to 24 Months, www.infactcanada.ca/whatsnew/vietnamlaw.html (accessed 15 December 2014)

Knight, L. (2002) 'Network Learning: Exploring Learning by Interorganizational Networks', Human Relations 55.4: 427-54

Knudsen, J.S. (2011) 'Company Delistings from the UN Global Compact: Limited Business Demand or Domestic Governance Failure?', Journal of Business Ethics 103.3: 331-49, http://papers.ssrn.com/sol3/papers.cfm?abstract id $=2139325$ (accessed 29 January 2015)

McKinsey \& Company (2004) Assessing the Global Compact Impact, http://europeandcis.undp.org/ guides/poverty/spd/ras/mckinsey_report_gc.pdf (accessed 15 December 2014)

Miretski, Pini Pavel and Bachmann, SaschaDominik (2012) 'The UN "Norms on the Responsibility of Transnational Corporations and Other Business Enterprises with Regard to Human Rights": A Requiem', Deakin Law Review 7.1: 5-41

Nestlé S.A. (2013) Nestlé in Society. Creating Shared Values and Meeting our Commitments 2013, www.unglobalcompact.org/system/attachments/ 75271/original/1_Nestle_2013_CSV_Full_ 
report_EN.pdf? 1397569643 (accessed

7 February 2015)

NGO (2006) Joint NGO Letter in Response to Interim Report of the Special Representative of the Secretarygeneral on Business and Human Rights, 18 May, http://germanwatch.org/tw/ruggie06.pdf (accessed 15 December 2014)

OECD (2011) Guidelines for Multinational Enterprises 2011 Edition, Paris: Organisation for Economic Co-operation and Development, www.oecd.org/daf/inv/mne/48004323.pdf (accessed 5 February 2015)

OHCHR (Office of the United Nations High Commissioner for Human Rights (2012) The Corporate Responsibility To Respect Human Rights. An Interpretive Guide, Geneva: United Nations, www.ohchr.org/documents/publications/ hr.pub.12.2_en.pdf (accessed 15 December 2014)

Paceth (n.d.) Case 1-2. Nestlé: The Infant Formula Controversy, www.paceth.com/ibus/nestle_case.pdf (accessed 15 December 2014)

Rasche, A. and Kell, G. (eds) (2010) The United Nations Global Compact. Achievements, Trends and Challenges, Cambridge: Cambridge University Press

Rasche, A.; Waddock, S. and McIntosh, M. (2013)

'The United Nations Global Compact:

Retrospect and Prospect', Business and Society 52.1: 6-30, http://papers.ssrn.com/sol3/ papers.cfm?abstract_id $=2293652$ (accessed 20 January 2015)

Ruggie, J.G. (2014) 'Quo Vadis? Unsolicited Advice to Business and Human Rights Treaty Sponsors', Human Rights and Business, 9 September, www.ihrb.org/commentary/quovadis-unsolicited-advice-business.html (accessed 5 February 2015)

Ruggie, J.G. (2013) Just Business. Multinational Corporations and Human Rights, (Norton Global Ethics Series), New York NY: W.W. Norton

Ruggie, J.G. (2001) 'The Global Compact as Learning Network', Global Governance 7.4: 371-8

Sell, S.K. (2003) Private Power, Public Law: The Globalization of Intellectual Property Rights, Cambridge: Cambridge University Press

Thérien, J.-P. and Pouliot, V. (2006) 'The Global Compact: Shifting the Politics of International Development?', Global Governance 12.1: 55-75

Tesner, S. (with the collaboration of George Kell) (2000) The United Nations and Business.

A Partnership Recovered, New York NY: St Martin's Press

Turner, M. (2004) 'Effort to Bury Mistrust', Financial Times, 24 June, www.ft.com/cms/s/0/ d1395dc0-c57d-1 1d8-bfb1-00000e2511c8.html \# axzz3QJFPkdQn (accessed 29 January 2015)

UNCTAD (2014) World Investment Forum 2014, http://unctad-worldinvestmentforum.org/ about-wif-2014 (accessed 15 December 2014)

UN DESA (United Nations Department of Economic and Social Affairs) (2014) Sustainable Development in Action: Special Report on Voluntary Commitments and Partnerships for Sustainable Development, New York NY: United Nations, https://sustainabledevelopment.un.org/ index.php?page $=$ view $\&$ type $=400 \& n r=$ 1479\&menu $=1682$ (accessed 29 January 2015) UNDP (United Nations Development Programme) (n.d.) Business Call to Action, www.undp.org/ content/undp/en/home/ourwork/partners/ private_sector/BCTA.html (accessed 15 December 2014)

UNDP (United Nations Development Programme) (2002) Results Based Management: Concept and Methodology, http://web.undp.org/evaluation/ documents/RBMConceptsMethodgyjuly2002.pdf (accessed 15 December 2014)

UNECE (United Nations Economic Commission for Europe) (n.d.a) $F F V$-Standards, www.unece.org/trade/agr/standard/fresh/ffvstandardse.html (accessed 15 December 2014)

UNECE (United Nations Economic Commission for Europe) (n.d.b) WP7 - Home, www.unece.org/trade/agr/welcome.html (accessed 15 December 2014)

UNICEF (n.d.a) Children's Rights and Business Principles, www.unglobalcompact.org/docs/ issues_doc/human_rights/CRBP/Childrens Rights_and_Business_Principles.pdf (accessed 15 December 2014)

UNICEF (n.d.b) Breastfeeding, www.unicef.org/nutrition/index_24824.html (accessed 15 December 2014)

UNICEF (2011) National Implementation of the International Code of Marketing of Breastmilk Substitutes, www.unicef.org/nutrition/files/ State_of_the_Code_by_Country_April2011.pdf (accessed 15 December 2014)

United Nations Global Compact (2014) Corporate Sustainability in the World Economy, New York NY: UN Global Compact Office, www.unglobalcompact.org/docs/news_events/ 8.1/GC_brochure_FINAL.pdf (accessed 15 December 2014)

United Nations Global Compact (2013) Global Corporate Sustainability Report, New York NY: UN Global Compact Office, www.unglobalcompact.org/docs/about_the_gc/ 
Global_Corporate_Sustainability_Report 2013.pdf (accessed 29 January 2015)

United Nations Global Compact and Office of the United Nations High Commissioner for Human Rights (OHCHR)(2011) The UN Guiding Principles on Business and Human Rights: Relationship to UN Global Compact Commitments, www.unglobalcompact.org/docs/issues_doc/ human_rights/Resources/GPs_GC\%20note.pdf (accessed 15 December 2014)

United Nations Human Rights Council (2014) Elaboration of An International Legally Binding Instrument on Transnational Corporations and Other Business Enterprises with Respect to Human Rights, A/HRC/26/L.22/Rev.1, 25 June 2014, http://daccess-dds-ny.un.org/doc/UNDOC/ LTD/G14/064/48/PDF/G1406448.pdf?Open Element (accessed 15 December 2014)

Utting, P. (2003) 'The Global Compact: Why All the Fuss?', UN Chronicle 1, www.unrisd.org/ unrisd/website/newsview.nsf/\%28httpNews\% 29/BC65635F3740379BC1256D010036BA3E? OpenDocument (accessed 29 January 2015)

Utting, P. (2000) UN-Business Partnerships: Whose Agenda Counts?, Geneva: UNRISD, www.unrisd.org/80256B3C005BCGF9/\%28http Publications\%29/A687857BD5E36114G1256C 3600434B5F?OpenDocument (accessed 29 January 2015)

Verkerk, R. (n.d.) 'The International Food Code of Codex Alimentarius', Ethical Consumer, www.ethicalconsumer.org/commentanalysis/ factsvgreenwash/codexalimentarius.aspx (accessed 29 January 2015)

Vogel, D. (2010) 'The Private Regulation of Global Corporate Conduct. Achievements and Limitations', Business and Society 49.1: 68-87
War on Want (n.d.) Brown Slated on 'Cynical' Poverty Event. 'Business Allies Given Free Ride on Rights Abuse', www.waronwant.org/component/ content/article/15854 (accessed 5 February 2015)

Weissbrodt, D. (2006) 'UN Perspectives on "Business and Humanitarian and Human Rights Obligations"', Proceedings of the Annual Meeting (American Society of International Law) 100: 135-9

Whitehouse, L. (2003) 'Corporate Social Responsibility, Corporate Citizenship and the Global Compact. A New Approach to Regulating Corporate Social Power?', Global Social Policy 3.3: 299-318

WHO/FAO (World Health Organization/Food and Agriculture Organization) (n.d.) Codex Alimentarius, www.codexalimentarius.org/ members-observers/en (accessed 15 December 2014)

WHO/FAO (World Health Organization/Food and Agriculture Organization) (2014) Codex Alimentarius. International Food Standards, www.codexalimentarius.org/standards/list-ofstandards (accessed 15 December 2014)

WTO (World Trade Organization) (1994) Agreement on the Application of Sanitary and Phytosanitary Measures, Annex A - Definitions, http://Wto.Org/English/Docs_E/Legal_E/ Legal_E.Htm (accessed 15 December 2014) Zammit, A. (2003) Development at Risk: Rethinking UN-Business Partnerships, Geneva: South Centre and United Nations Research Institute for Social Development 